\title{
DISCOURSES THAT MATTER: WOLE SOYINKA'S THEATRE AS A FORM OF REPRESENTING AND READING THE WORLD
}

DISCURSOS DE REFERÊNCIA: REPRESENTAÇÃO E LEITURA DO MUNDO ATRAVÉS DO TEATRO DE WOLE SOYINKA

DISCURSOS DE REFERENCIA: REPRESENTACIÓN Y LECTURA DEL MUNDO A TRAVÉS DEL TEATRO DE WOLE SOYINKA

\section{Rosa Branca Figueiredo (rbranca@ipg.pt)*}

\section{ABSTRACT:}

Wole Soyinka is a most significant figure in contemporary world literature. From the perspectives of the politics of postcolonial writings, perhaps the ultimate challenge of the complexity of Soyinka's works and career lies in the fact that the metanarratives that imaginatively and discursively underwrote the great liberation movements of the twentieth century do not feature in his works in their conventional and familiar configurations. Overarching all the struggles waged by these movements is the struggle for self-representation as the existential and expressive roots of human freedom. The best examples of this structure in Soyinka's theatre are A Dance of the Forests, Kongi's Harvest, Madmen and Specialists and From Zia With Love. Soyinka's critical essays also operate in a great variety of social and intellectual contexts and cover an extraordinary range of topics, including literary criticism and aesthetic theory, theatre and cultural history, political power and ideology, and, more recently religious extremism and nuclear pollution. One "form of attention" which has been influential in the reception of Soyinka's works is that of professional critics, especially with regard to the institutionalisation of the academic study of Anglophone writings of the developing world in the second half of the twentieth century.

Key-words: Soyinka, postcolonial theatre/discourse, cultural identities, African literature.

\section{RESUMO:}

Wole Soyinka é uma figura proeminente na literatura mundial contemporânea. Partindo da perspetiva da política de escrita pós-colonial de expressão inglesa, o desafio da complexidade da vida e obra do dramaturgo reside no facto de as meta-narrativas, que de forma imaginativa e discursiva estiveram na base dos grandes movimentos de libertação do século XX, não se apresentarem na 
escrita Soyinkiana de forma convencional. Acima de todas as lutas desencadeadas por estes movimentos está a luta pela auto-determinação, raíz existencial e expressiva da liberdade humana. Os melhores exemplos desta demanda no teatro Soyinkiano encontram-se em peças como A Dance of the Forests, Kongi's Harvest, Madmen and Specialists and From Zia With Love. Os ensaios críticos de Soyinka operam, de igual forma, em variadíssimos contextos sociais e intelectuais cobrindo um extraordinário leque de tópicos, que vão desde a crítica literária à teoria estética, do teatro à história cultural, do poder político à ideologia, e mais recentemente, do extremismo religioso à poluição nuclear. Um tipo de atenção que tem sido decisivo na receção da obra de Wole Soyinka é a dos críticos literários profissionais, particularmente no que diz respeito a institucionalização do estudo académico da escrita anglófona do mundo em desenvolvimento na segunda metade do século XX. .

Palavras-chave: Soyinka, Teatro pós-colonial, identidades culturais, literatura africana.

\section{RESUMEN:}

Wole Soyinka es una figura prominente en la literatura del mundo contemporáneo. Partiendo de la perspectiva de la política de la escritura postcolonial de la expresión inglesa, el desafío de la complejidad de la vida y obra del dramaturgo está que las meta narrativas, que de manera imaginativa y discursiva estuvieran en la base de los grandes los movimientos de liberación del siglo $X X$, no se presentan en la escrita de Soyinka de modo convencional. Sobre todo las luchas empezadas por estos movimientos están la lucha por la autodeterminación, raíz existencial y expresiva de la libertad humana. Los mejores ejemplos de esta busca en el teatro Soyinkiano esta en obras como Dance of the Forests, Kongi's Harvest, Madmen and Specialists and From Zia With Love. Los ensayos críticos de Soyinka funcionan de igual manera, en numerosos contextos sociales e intelectuales cubriendo una extraordinaria gama de temas, que van desde la crítica literaria a la teoría estética, del teatro al la historia cultural, del poder político a la ideología, y más recientemente, del extremismo religioso a la contaminación nuclear. Una clase de atención que ha sido decisiva en la recepción de la obra de Wole Soyinka es la crítica literaria profesional, particularmente con respecto a la institucionalización del estudio académico de la escrita anglófona en el mundo en desarrollo en la segunda mitad del siglo $X X$.

Palabras clave: Soyinka, Teatro postcolonial, identidades culturales, literatura africanaPh 
Ph.D. in Theatre Studies, University of Lisbon with a thesis on the Nigerian Laureate playwright Wole Soyinka. Researcher at the Research Unit for Inland Development of the Polytechnic Institute of Guarda., and a collaborator at the Centre for Theatre Studies at the University of Lisbon. Recent publications include essays on Multilingualism, Multiculturalism,

Cultural Identities, Ritual and African Drama. Associate Professor / Erasmus Coordinator 
Wole Soyinka, Nigeria's leading dramatist, is a most significant figure in contemporary world literature. From the perspectives of the politics of postcolonial writings and the progressive formations of the postcolonial discourse, perhaps the ultimate challenge of the complexity and difficulty of Soyinka's works and career lies in the fact that the metanarratives that imaginatively and discursively legitimated the great liberation movements of the twentieth century do not feature in his works in their conventional and familiar configurations. These movements include the anti-colonial revolutions which pitched colonies against empires; the class struggles of working people and the poor for better conditions of life and work; the struggles for gender equality in the home, in the workplace and for the control of bodies and reproductive rights. And overarching all the struggles waged by these movements is the struggle for self-representation as the existential and expressive roots of human freedom.

It is a remarkable feature of Soyinka's writings that the metanarratives that legitimated the struggles of these social movements - to which Soyinka has undoubted deep ideological allegiances appear in his writings as fragments, and nearly always in ironic deformations. The best examples of this structure in Soyinka's theatre are A Dance of the Forests, Kongi's Harvest, The Road, Madmen and Specialists and From Zia With Love. In this matter Soyinka consistently subjects the metanarratives of the emancipation of colonized societies and subaltern groups to a severe and sceptical inspection which is sometimes playful, ludic, and funny but also often grimly sardonic and nihilistic.

Soyinka's critical essays also operate in a great variety of social and intellectual contexts and cover an extraordinary range of topics, including literary criticism and aesthetic theory, theatre and cultural history, political power and ideology, and, more recently religious extremism and nuclear pollution. They are an uneven achievement, at times crisp and incisive, at times couched in a lugubrious jargon and written in dense, intricately threaded sentences that are difficult to disentangle. In large measure, the disquiet often expressed about Soyinka's mode of artistic avant-gardism by critics and theorists closely identified with particular social movements, derives from this point.

The slipperiness of Soyinka's critical prose, for example is partly a matter of content, partly of context. The essays, many of them originally lectures, were written out of diverse situations over a period of thirty years and presented to widely different audiences. For example, the early essay "The Writer in a Modern African State" (1967), in which Soyinka uncharacteristically decries "mythology" in favour of urgent contemporary relevance, came out of the national "collapse of humanity" 
in the Biafra crisis of (1966) (Art, Dialogue and Outrage, 17,20), and his 1975 redefinition of the special "strong breed" of his 1963 carrier drama as "just ordinary human beings like you and me" reflects a felt need for public altruism and sacrifice during the political megalomania of the Gowon years (Gates 1986, 60).

There are crucial contextual differences between a highly reflective, cerebral course of lectures on African culture delivered to unreceptive Cambridge academics and an address to a predominantly black American audience in search of authentic dramatic idioms compatible with the cause of black revolution. No doubt, also, the strong antiEuropean polemic and refusal to accommodate Western audiences that are such marked features of both the collection of essays Myth, Literature, and the African World and the tragedy Death and the King's Horseman were partly the fruit of Soyinka's experiences in an English cultural backwater that in 1975 had not heard of African Literature and forced the visiting fellow to give his lectures in the Anthropology Department. ${ }^{48}$

Even though there is certainly a great deal of competent criticism of African literature, there still is something of a tendency to think uncritically in terms of these contrasting categorizations - especially "communalistic" vs. "individualistic" - without the necessary distinctions and caveats in mind. These categorizations encourage the misrepresentation of certain literary works, the underestimation of their human complexity and ambiguity, and the diminishing of their merit, when they are imposed on literature structured in different terms. I would like to examine the comment of a critic who serves as example of these tendencies: a social scientist commenting on Wole Soyinka's The Lion and The Jewel, among other African works.

In his article, "Behavior and Cultural Value in west African Stories: Literary Sources for the Study of Culture Contact" 49 Austin Shelton argues that Wole Soyinka's play, The Lion and The Jewe/ reasserts the value of traditional, communally-based society. Soyinka's comedy concerns the victory of a chief over a superficially Westernized schoolteacher in a rivalry for a village belle - whose head has been a bit swelled as a result of the appearance of her photograph in a glossy Lagos magazine. The play is assessed as follows: "The value most clearly approved is traditional communal responsibility, revealed partly in the condemnation of self-seeking individualism" (411). Now the play does mock "modern" ways, but particularly insofar as they are espoused superficially, naively, or hypocritically by Lakunle, the village

\footnotetext{
${ }^{48}$.See Preface to Myth, Literature and the African World, Cambrige, 1976

${ }^{49}$ In Black Africa: Its People and their Cultures Today, edited by John Middleton, London, 1970, 406-12
} 
schoolteacher. In this sense, what is being exposed, as in comedies generally, is pretension. The categories of approved traditionalism involving positive qualities ("responsibility") and disapproved modernism involving negative qualities ("self-seeking") may derive from the literature that celebrates or seeks unique ethical values in African social institutions, but they are not the categories that structure this play. To come to the play with these preconceived notions in mind is to miss the comedy. The comic stance is a more objective one. As comedy, The Lion and The Jewe/ exposes self-seeking and inconsistency - beneath various guises - in all characters. It shows how people use the "traditional" for "modern" purposes, and the "modern" for "traditional" purposes, in accordance with universal human motivations of pride, power, and sex, rather than out of loyalty to an abstraction such as "tradition", or even primarily out of religious or moral conviction. If "tradition", as exemplified by chief Baroka, wins (in the sense that Sidi the belle becomes his youngest wife), it is mainly because he is wilier than Lakunle, not because he has appealed to better values, which in themselves motivate behavior. Baroka and Lakunle may not be equally good choices as mates, for economic and other reasons, but the chief is equally subject to the penetrating comic glance that distinguishes the eloquent speech from the mundane motive.

"Traditional" and "modern", especially as they are attached to positively-evaluated "communalism" and negatively-evaluated "individualism", may be rather meaningless and indeed misleading ready-made categories to use in the analysis of modern African literature. One suspects that such categories would also be troublesome for the social scientist. Soyinka's play seems very much related to the work of those anthropologists concerned with the selective adaptation to new institutions, and the incorporation of new ideas or practices into existing institutions, in situations involving rapid change, such as that of modernizing Africa. Soyinka's characters would easily fit into a world where a practitioner of folk medicine may live in an urban community and be saving money to send his son to college, or where bride-price becomes a matter of cash and is raised exorbitantly by parents of daughters. One danger of the categories is the assumption that change is an all-or-nothing experience. Another is that people act out of loyalty to abstractions, rather than in accordance with their needs, upon which many complex fators operate, including their socialization into their own systems.

The tendency to use such concepts as "traditional" and "modern", "communalistic" and "individualistic" too carelessly and abstractly, without sufficient content in mind, and without regard for their fit with the literature being examined, is undoubtedly encouraged by the critic's 
awareness of what African intellectuals themselves have said, often for political purposes. Shelton does begin with the assumption that the African writer, like his society is inherently communally-oriented, opposed to "any consideration of African literature as individualistic 'art for art's sake'". He argues that the new African Literature is reasserting a "traditional" African attitude toward art as "socially functional rather than merely aesthetically pleasing" (406).

Soyinka rejects the simple formula that produces the kind of work that would fit Shelton's reading of The Lion and the Jewer. "A society, an intrusion, an all too predictable conflict" (9). Even if the writer in the emerging African national states understandably felt that he had to "postpone that unique reflection on experience and events which is what makes a writer - and constitute himself into a part of that machinery that will actually shape events," Soyinka suggests that the writer cannot be truly useful politically if, once again, he ignores the truth, becoming "blinded to the present by the resuscitated splendours of the past" 50 . As he explains his attitudes about the political role of the writer in the essay "The Writer in a Modern African State", Soyinka is undoubtedly thinking of the Nigerian Civil War, during which he was imprisoned for supporting the Biafran cause:

This was the beginning of the abdication of the African writer and the deception which he caused by fabricating a magnitude of unfelt abstractions . The black tin-god would degrade and dehumanise his victim as capably as Vorster or Governor Wallace . The romancer and the intellectual mythmaker has successfully deleted this black portion of a common human equation. The myth of irrational nobility, of a racial essence that must come to the rescue of the white depravity has run its full course. ${ }^{51}$

In accordance with these opinions, while some of Soyinka's plays do comment on materialism, they do not make "humanity" an inherent possession of Africans, nor do they associate the ethical life exclusively with traditional ways. As satirist, Soyinka shows the potential for exploitation in the older societies as well as the new - that is, he portrays humans. In Kongi's Harvest, both the traditional rulers and the new political leaders are clearly portrayed as subject to the same kinds of motivations. Furthermore, he may use the comparison of traditional and modern to touch on issues beyond it; in The Swamp Dwellers,

\footnotetext{
${ }^{50}$ In Black Africa: Its People and their Cultures Today, edited by John Middleton, London, 1970,16,18

${ }^{51}$ Ibidem, 17
} 
neither the old religion (which is exploited by the cult priest) nor the new life in the cities can guarantee that there will be no risk, no loss in life. ${ }^{52}$ Preconceptions about political or social attitudes and too hasty an attempt to generalize in terms of the "traditional" and the "modern", the "communalistic" and the "individualistic" can result in serious misreading of sophisticated literature, particularly when written by an author of Soyinka's cast of mind.

It is probably safe to say that we are still too close to these works and to their author to be able to make any definitive assessments of each work and of the entire corpus. Inevitably this leads to one of the most important, but so far largely unresolved issues of textual exegesis and socio-historical explanation in Soyinka criticism to date. This pertains to the great theoretical and practical investment of Soyinka's writings and career, taken as a whole, in being representative of the capacity of the heritage of imagination and spirit in Africa to respond adequately and even powerfully to the challenges and dilemmas of modernity as African peoples and societies have experienced them through colonial capitalism and the ravages of neo-colonial marginalization in the global order of "late", transnational capitalism. In inscriptions interpreted by Biodun Jeyifo in his recent book on Wole Soyinka, as homologies of the self and the social, Soyinka has in nearly all his major works approached these challenges and dilemmas through the imaginative prism of what he deems inextricable dualities in nature and human existence in general, but with particular regard to the phenomenon of violence: destruction and creation, reactionary terror and restorative, cleansing bloodletting. There is a metaphysical dimension to this conception of violence and Soyinka's theoretical essays and imaginative writings are topheavy with images and tropes from nature and from what he calls "nuomenal forces" to shore up this metaphysics. But there is a pragmatic, even revolutionary sociology involved as well, for Soyinka has never abandoned his consuming need to expose and debunk the reactionary, sel-serving terror and violence of corrupt, tyrannical despots, even if he has steadfastly refused to romanticize and idealize the counter-hegemonic violence of his great protagonist characters and their followers. This is indeed why these protagonist characters of Soyinka's most ambitious works are men of violence who carry within themselves part of the evil which they oppose and try to confront by violently jolting complacencies of custom and thought in their societies. Jeyifo further asserts that at the bottom of Soyinka's artistic sensibilities and political activism is a profound and unflinching preoccupation with the place of violence in human affairs.

\footnotetext{
52 See Gerald Moore, Wole Soyinka, New York, 1971, 16-19.
} 
Soyinka's aesthetic philosophy, as formulated in a densely symbolic essay like "The Fourth Stage" or essays of great clarity and eloquence like "The Writer in a Modern African State" and "Climates of Art" is one founded on the generativity and the contradictoriness of violence. According to Jeyifo, violence in this conception is both productive and destructive, both potentially reactionary and revolutionary, depending on matters of circumstance, interests and will. If anything gives coherence to the extraordinary range of our author's activist involvements and interventions in the political life of his country in the last four decades, it is this utter preparedness not to flinch from the seeming central place of violence in human affairs, either in consolidating the reign of terror and repression in Africa and other regions of the world or, conversely in mobilizing effective opposition to the violence of the rulers as sedimented in the instruments of force and coercion.

In the dominant strains of Soyinka criticism, the Nigerian author's metaphysics and pragmatics of violence and evil as forms of representing and reading the world have been more or less accepted on their own terms and based on this, much has been written that is useful for the light that it sheds on the sources of the symbolic and imaginative richness of Soyinka's most important works of fiction, drama and poetry.

I would like to finish this paper by quoting Biodun Jeyifo again and emphasise my total agreement with this critic when he says that:

It is time to go with Soyinka's most ambitious and challenging works like A Dance of the Forests, The Road, Madmen and Specialists, Death and the King's Horseman, A Shuttle in the Crypt. The Bacchae of Euripides, Isara, and Outsiders and read them complexly and comparatively as appertaining both to Africa and the developing world and the whole of humanity. This radical hermeneutic act can be helped if we secularise and historicize the significations of these "worlds": the ancestors, living generations and unborn denizens of the world are co-extensive in the ways that the defeats, victories, energies and capacities of the precolonial and colonial pasts are still residually with us in the postcolonial present and future, just as "structures of feeling" of the epochs of precapitalism and capitalism still haunt the present of late capitalism, with important intimations and portents for our future postcapitalist world. (Jeyifo 2004, 288) 
BIBLIOGRAPHY:

Agetua, John (1973). Interviews with Six Nigerian Writers, Benin City, Bendel Newspaper Corporation.

Asagba, Austin O. (1986). Roots of African Drama: Critical approaches and Elements of Continuity. Kunapipi3 (3) : 84-99.

Duerden, D. and C. Pieterse, eds. (1972). African Writers Talking, London, Heinemann Educational.

Gates, H. Louis Jr. ed. (1986). "Race", Writing and Difference, Chicago, The University of Chicago Press.

Gibbs, J. and B. Lindfors, eds. (1993). Research on Wole Soyinka, Trenton, Africa World Press, Inc.

Gilbert, H. and J. Tompkins (1996). Post Colonial Drama: theory, practice, politics, London, Routledge.

Griffiths, Gareth (2000). African Literatures in English, Harlow, Longman.

Jeyifo, Biodun (1988). Perspectives on Wole Soyinka: Freedom and Complexity, Mississippi, University Press of Mississippi.

(2004). Wole Soyinka: Politics, Poetics and Postcolonialism, Cambridge, Cambridge University Press.

Jones, Eldred D. (1983). The Writing of Wole Soyinka, London, Heinemann.

Katrak, Ketu H. (1986). Wole Soyinka and Modern Tragedy: A Study of Dramatic Theory and Practice, Westport, Conn. Greenwood Press.

Maja-Pearce, Adewale, ed. (1994). Wole Soyinka: An Appraisal, Oxford, Heinemann.

Moore, Gerald (1971). Wole Soyinka, New York.

Msiska, Mpalive-Hangson (1988). Wole Soyinka, Plymouth, Northcote House Publishers Ltd. Shelton, Austin. (1970). Behavior and Cultural Value in West African Stories: Literary Sources for the Study of Culture Contact. In Black Africa: Its People and their Cultures Today, edited by John Middleton, London, 406-12.

Soyinka, Wole (1973). Collected Plays (vol.1), Oxford, Oxford University Press.

(1974). Collected Plays (vol.2), Oxford, Oxford University Press.

(1975). Death and the King's Horseman. London: Methuen Drama.

(1976). Myth, Literature and the African World, Cambridge, Cambridge University Press.

(1988). Art, Dialogue and Outrage: Essays on Literature and Culture, Ibadan, Nigeria, New Horn Press (distributed in England by Hans Zell, Oxford).

(1999). The Burden of Memory, The Muse of Forgiveness, Oxford, Oxford University Press.

(1999). Wole Soyinka: Plays 2, London, Methuen Drama.

Wright, Derek (1993). Wole Soyinka Revisited, New York, Twayne Publishers. 
Eqitania

sc i e c i a 
Eqitania

sc i e c i a 
Indexação da Revista

Latindex

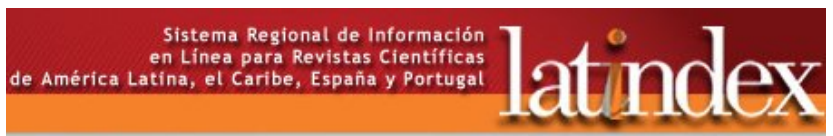

Copernicus

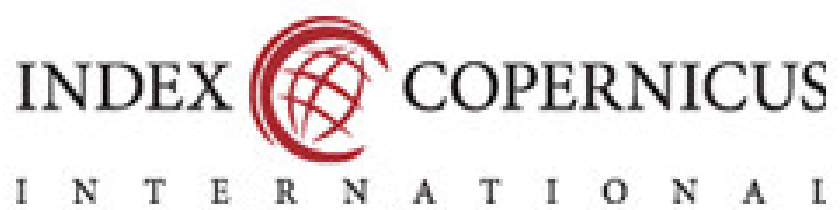

Base de Dados em que consta a revista

Proquest

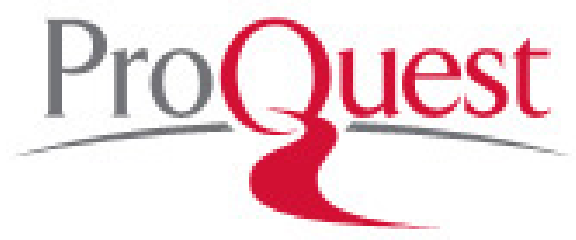

EBSCO

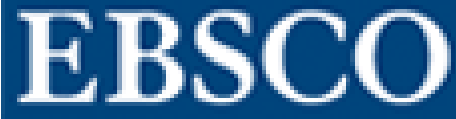

